\title{
EFL Students' Strategy in Reading English Text in Perspective Automatic Information Processing (AIP)
}

\author{
Resyi Fatmawati \\ resyi.fatmawati17140@student.unsika.ac.id \\ Yousef Bani Ahmad \\ yousef.baniahmad@fkip.unsika.ac.id \\ Sumarta \\ litcomnet@yahoo.co.id \\ Universitas Singaperbangsa Karawang
}

\begin{abstract}
Currently, students are asked to be able to understand literacy in reading. However, to understand literacy, of course, it has to go through the right strategy especially to beginner reader students. The purpose of this study is to determine the strategy of students in reading English text through perspective from automatic information processing (AIP) in reading. The method for this study used interviews and observations of one participant conducted in the second-level high school. This study also uses descriptive case study as research design. This study shows 5 things that should be reviewed in reading English text, namely attention, decoding, comprehension, switching in reading and automaticity. However, the five things found in this study are still rarely noticed. Therefore, this study also aims to allow educators and students to know what steps to do as a strategy to be able to read and understand the text of reading in English especially for beginner reader.
\end{abstract}

Keywords: Reading Strategy; English Text; Automatic Information Processing

\section{INTRODUCTION}

Hittleman (1978:5) states that "reading is a verbal process interrelated with thinking and with all other communication abilities: listening, speaking, and writing". From that statement, reading is a skill that relate with other English skills such as writing, listening and speaking. Because, when we read, we speak, when we read, we learn what are written, when we read, we also learn how to listen English texts. Also, Harris \& Sipay (1980:8) state that "Reading is the meaningful interpretation of printed or written verbal symbols. Thus, in learning reading, we not only learn about genre of text but also, we learn about the meaning and we have to understand it. In contrast, learning to read English in Indonesia still has many problems such as the students still difficult to understand what they read, that why they sometimes read in the heart. Then, they just answer the questions related to the text they read. It does not involve thinking process and they do not communicate each other. 
To avoid passive learning, the teachers of English should have many strategies to build students' thinking process, students' activities, students' communications and students' involvement during reading class. The use of suitable strategy that will be determine in teaching reading should be able to guide students to read comprehensively. In spite of teacher strategies has a lot of variation, thus, students' attentions before or during reading still worth nothing. Therefore, this study focuses on how EFL students' strategy in reading English Text in Perspective Automatic Information Processing (AIP).

\section{Previous Related Study}

Reading strategy may no longer be a strange thing among educators, many teachers have unique strategies in teaching reading. As shown at previous researches, the thesis which done by Noor Aziz Kurniawan (2017), by the title "Teaching Strategies Use In Reading Comprehension Class at The Tenth Grade Students Of SMK Islam Sudirman 2 Ambarawa". The result of his research that the strategies memorizing, questions and answer relationship, games and discussion are effective to make students comprehend in reading. In addition, the thesis from Rio Gusti Ranggi (2019), by the title "Teacher Strategies in Teaching Reading Comprehension at The Third Grade of State Junior High School 23 Jambi". The result of his research is that the strategies use in the class are effective to comprehend the students' reading skill. Besides that, it shown at thesis which done by Leli Sari (2017), the thesis by the tittle "Improving Reading Comprehension Through Directed Reading Thinking Activity Strategy for the Eight Grade Students of SMP Negri 17 Medan". Then, from her research found that DRTA strategy has a characteristic as planning, action and reflection. The result of her research that using DRTA is effective strategy for comprehending students reading ability.

\section{Reading}

Reading is a brunch of English skill that should be mastered by students and teachers in academic area. There are many experts that define reading skill which stated by Hesham (2005), reading is the action to obtain the knowledge through the text. Reading also can be called as interactive activity between reader and the text which leads an automaticity. From Hesham's statement, by reading, the students can transform the text into information. Reading also can make students more critical in thinking. Then, reading can help students to get new vocabulary. Also, reading is about how the students interact with the text automatically. Further, Reading is the method to acquire the information or the message of the text so the readers should gain the main idea of the text that they read, Grabe (2000). From Grabe statements shows that reading as a process activity to gain the information from what the people read. As it can be concluded that reading is a process where mental development is needed to stimulate the eyes, ears and mouth. Reading is also an activity that involves concentration as a reader. In addition, Reading also helps readers to decipher new words and phrases that they come across in everyday conversation, Haris (2002). In the same way, reading is also a process where the readers can get or know the new vocabulary from what the read for their daily conversations. 


\section{Reading Comprehension}

Reading comprehension is the interaction of information in which the readers draw information from a text and the readers expectations about the text that already has been read (Walter, 2004). It means that reading comprehension is the skill on how the students understand the text that they have read. Moreover, Comprehension is the ability to understand completely and be familiar with a situation, fact, etc. (Caldwell, 2008). From Caldwell's statements, it can be concluded that comprehension means that students can understand their situations, the fact that happened in their environment. Hence, According to Klingner (2007:2), reading comprehension is the process of constructing meaning by coordinating a number of complex process including word, understanding the meaning and the relationships between ideas conveyed in a text. In conclusion, reading comprehension is the ability that students should to understand text from the basic element of reading skill such as decoding the word, translating unfamiliar words. Next, Hillerich (1983:126) Classified Reading Comprehension into three levels: Literal Comprehension, Inferential Comprehension, Critical comprehension. literal comprehension level requires the reader to retell the information that are overtly stated in the text by using their own words. For examples: it is to recall names, things, and areas. Then, the inferential comprehension level means that students as a readers can process the deeper meaning from the information that they get from text. the critical comprehension level of shrewdness of validity or worth of what the readers have read or heard. From those criteria, it seems that reading comprehension should be mastered to the readers from the basic levels.

\section{Reading Strategy}

Reading strategy can be prescribed as a plan method, reading activities that designed in academic achievement to particular goals. It means that reading process involves process of how students or readers know the nature of text, the purpose of the text and the context of the situation that included into the text. Also, Brown (2004) has classified strategies into two kinds. The first kind is direct strategies or what are also called cognitive strategies. These include a number of different ways of remembering more effectively and of using all possible cognitive processes and compensating knowledge. The second kind is indirect strategies which focus on some aspects, such as organizing and evaluating learning, managing the emotions and learning from others. Afterward, Duffy (2007) has mentioned some strategies for teaching reading comprehension in the classroom. First, teaching of reading is knowledge-based. Thus, teachers are acquired to have knowledge related to the material so that they can explain the material to their students. For instance, to teach reading, the teachers should have a large of knowledge to share. Then, the teacher also able to explain material to the students. According to Brown (2004, p. 229), there are some strategies of reading comprehension: First, the teacher needs to identify the purpose of the reading. It is important that she have a clear purpose to help her to narrow the choice of book from a reading list, then once she has chosen a book, to select the best chapter(s) and section(s). Having a clear purpose also helps students to locate the most useful part of the text for their needs and to ignore those parts which will not help them. Efficient reading consists of identifying the purposes in 
reading something so that we know what we are looking for and can weed out potentially distracting information; Second, ensure there are graphics and pictures to help beginners in decoding and comprehension (for beginning level learners). Alternatively use efficient silent reading techniques for relatively rapid comprehension (for intermediate to advanced levels).

\section{METHOD}

\section{Research Design and Sample}

The Design of this research is case study. The one purpose of case study is to know the case or the phenomena that happen in the class or environment. This study was done at one of senior high school in Karawang. The sample or the participant of this study was conducted by one participant that taken from second grade of senior high school.

\section{Instrument and Procedures}

The instrument of collecting the data from this study used interview and observation. Interview is used for getting in information from the students deeply and this study use structure interview. The interview was done after the student got reading class by using automatic information processing (AIP) in reading skill. The researcher conducted the interview directly face to face with the participant with several questions. Then, observation is used to strengthen the data. The observation was done during the class. The researcher also took the video during the observation in order to make the prove of observation process.

\section{Data Analysis}

After getting in information from the interview and observation, so the researcher going to analyze the data. To analyze the data, the researcher used thematic analysis by Braun and Clarke (2016). Thematic analysis is the term to find out the themes and also to interpret and make a sense of the data. In thematic analysis, there are six phases that shown as become familiar with data, generate initial codes, search for themes, review the themes, define the theme and write up the data or interpretation.

\section{RESULT AND DISCUSSION}

This research finding was collected by using two data instruments namely interview and observation. This finding shown that automatic information processing in reading skill can be analysed by five finding: attention, decoding, comprehension, switching in reading, and automaticity.

\section{Attention}

At attention, there are two aspects that can be analyze from the students' attention; internal attention and external attention. Internal attention comes from students' 
internal aspect while external attention is the attention that can be influenced around the environment. Students' perception on their attention in reading can be formulated by using interview and observation.

\subsection{Interview of Internal Attention}

From the interview section, internal attention shows three factors, they are alertness, selectivity and limited capacity. The finding from alertness shows that English is rather difficult to pronounce. So that, the participant should try to start reading by text that usually see and hear. As it shows from the first participant with the transcript below

“...saya tidak terbiasa membaca dalam bahsa inggris. Bagi saya Bahasa inggris masih sukar untuk dilafalkan" (P1, line 2, no1).

"...untuk memulai menyukai teks bahasa inggris, biasanya saya memulai dari kalimat yang sering saya dengar dan yang sering saya lihat” (P1, line 2, no 2). The internal attention also comes from selectivity of the participant in which can be found from the participant that to try to like reading English text, the participant can start from reading an inspiring story from world leaders and to operate the visual mode, the participant finds out the free time to be focus. As it is shown in the transcript below

“...biasanya saya sering membaca cerita yang menginsfirasi dari tokoh-tokoh dunia dengan itu saya bisa belajar Bahasa inggris" (P1, line 2, no 3).

“...agar dapat mengoprasikan visual mode sebelum membaca, saya harus mencari waktu luang agar bisa focus membaca” (P1, line 2, no 4).

The last of internal attention is limited capacity. In limited capacity, there were found that limited capacity influenced by limited knowledge. In this page, it is found by the first participant that to defeat limited capacity in reading, the participant tries to read English magazine or newspaper. As it shows in the transcript the first participant below.

“...saya selalu memcoba membaca majalah atau newspaper yang teks bacaanya sedikit atau yang bacaannya tidak membosankan” (P1, line 4, no 5).

\subsection{Interview of External Attention}

From the data of the interview of external attention show the two points influenced by the orienting behavior and maximize the information input. Thus, the first participant stated that to orient behavior before reading, the participant starts to look for good position, good mood and quite place. Then, to maximize the information input, the participant translates the text into Indonesian to know the meaning of the text. It can be seen in the interview transcript below

“...sebelum membaca, biasanya saya selalu mempersiapkan diri dengan mencari posisi yang enak. Selain itu, harus disaat mood yang bagus serta mencari tempat yang sepi" (P1, line 2, no 6).

“...untuk mendapatkan informasi dari teks yang saya baca, biasanya saya menterjemahkan teks tersebut kedalam Bahasa Indonesia dengan mengguakan kamus atau mencari di google translate" (P1, line 2, no 7). 


\subsection{Observation of the Attention.}

The observation from the participants shows that internal attention influenced by three aspects as alertness, selectivity and limited capacity. As it shows from the participant who select the text which likes the most before reading (minute 00:30). external attention shows two points as orienting behavior and maximize the information. It can be seen by the participant that to maximize the information input, the participant read the text completely. Then, the participant tags which word that the participant does not know the meaning (minute 02: 37).

\section{Decoding}

\subsection{Interview}

As stated by the participant, it found that decoding is done by looking for dictionary and translate the word that participant does not know. As it shown in the interview transcript by the participant below

“...saya biasanya menyiapkan kamus yang realiable” (P1, line 3, no 8).

"...biasanya saya menerjemahkan kata didalam teks jika kata tersebut asing saya dengar juga jika kata tersebut memiliki makna yang ambigu" (P1, line 1, no 9).

\subsection{Observation}

Form the data of Observation, pointed in minute 03:31, before decoding the word, the participant reads the text per paragraph and begins to decode or translate the word which participant does not know meaning of the word by tagging it.

\section{Comprehension}

Comprehension is the way how students understand the text. In this part, there was two aspects that can be found such as interrelate the word and combine the separate meaning.

\section{1 interview}

From the interview, it shows that the participant interrelates the word by reading entirety and reading per paragraph repeatedly. Then, to combine the separate meaning, the participant looks into dictionary and choose the right one of the meaning. Here is the transcript of the interview by the first participant

"...untuk memahami teks bacaan dalam Bahasa inggris, saya biasanya membaca teks dengan secara keseluruhan lebih dan dari satu kali. Setelah itu saya membaca perparghraf teks" (P1, line 2, no 10).

“...untuk memahami makna yang terpisah didialam teks, saya selalu membuka kamus untuk mecari arti dara kata tersebut. Setelah itu, jika tidak ada didalam kamus, saya mencari kalimat yang tepat untuk memaknai kalimat tersebut dengan mencari makna yang tepat" (P1, line 2, no.11).

\subsection{Observation}


In the observation, there are two aspects that can be found such as interrelate the word and combine the separate meaning. As shown in minute 04:00, the participant interrelates the word and combine the separate meaning by translating the word using dictionary.

\section{Switching in Reading}

In switching reading, the participant decodes the word to understand reading text. The data was supporting by interview and observation.

\subsection{Interview}

From an Interview data, the participant states that decoding is important to know the word classes. As it shown it the transcript below

"...karena dengan mendecode kata, saya bisa mengetahui word classes" (P1 line 1, no 12).

\subsection{Observation}

It shows that decoding process help student to understand the word. As it shown by the participant who decode the word 'especially ' at the first paragraph line 2 (minute 04:10), 'should' at the first paragraph line 2 (minute 05:00), 'recently' at the first paragraph line 4 (minute 05: 58), 'using' at the second paragraph line 1 (minute 06: 36), 'necessary' at paragraph 2 line 2 ( minute 07: 34), 'watch' at paragraph 2 line 3 (minute (08: 07), 'cannot' at paragraph 3 line 1 (minute 09:31), 'which' at paragraph 3 line 4 (minute 10:21), 'strangers' at paragraph 3 line 6 (minute 10:35).

\section{Automaticity}

\subsection{Interview}

Automaticity related to how the participant turn their attention to get meaning from the reading text. It is stated by the first participant that to turn the attention to get the meaning of the reading text, the participant can look for the theme that discussing at the beginning and the ending of the text. As it shown by interview data transcript with the first participant below

"...: untuk memahami teks dalam Bahasa inggris secara otomatis, saya harus mencari tema dari bacaan, pembahasan awal dan akhir dari teks bacaan tersebut" (P1 line 2, no 13).

\subsection{Observation}

From the observation, it shows how the participants turn their attention to get the meaning of the text. As it shown by the participant (minute 03:07), the first participant trying to reads the text per paragraph. 


\section{CONCLUSION}

Based on result finding and discussion about Automatic Information Processing in Reading Skill: EFL Students' Strategy in Reading English Text. The result found that the participant is not accustomed to reading English. Then, participant has to read repeatedly to know the meaning of the text. Thus, the participant also should master vocabulary as much as possible.

\section{REFERENCES}

Akmal, S., Dhiyah, I., \& Mulia. (2020). Investigating students' interest on reading journal articles: Materials, reasons and strategies. Studies in English Language and Education, 7(1), 194-208

Asrifan, A., \& Raskova Octaberlina, L. (2021). The cooperative integrated reading and composition (CIRC) strategy in teaching reading comprehension teaching comprehension. https://doi.org/10.14293/s2199-1006.1.sor-.ppmy3fc.v1

Dwiningtiyas, G. N., Sofyan, D., \& Puspita, H. (2020). Teachers' strategies in teaching reading comprehension. JALL (Journal of Applied Linguistics and Literacy), 4(2). https://doi.org/10.25157/jall.v4i2.3682

Elleman, A. and Oslund, E., (2019). Reading Comprehension Research: Implications for Practice and Policy. Policy Insights from the Behavioural and Brain Sciences, 6(1), pp.3-11.

Nurdianingsih, F. (2021). Teachers' strategies in teaching reading comprehension. PROJECT (Professional Journal of English Education), 4(2), 285. https://doi.org/10.22460/project.v4i2.p285-289

Rastegar, M., Mehrabi Kermani, E. and Khabir, M., (2017). The Relationship between Metacognitive Reading Strategies Use and Reading Comprehension Achievement of EFL Learners. Open Journal of Modern Linguistics, 07(02), pp.65-74.

Sumiati, C., Zulkaidah, D., \& Kaswan, K. (2019). Teaching reading comprehension using jigsaw technique. PROJECT (Professional Journal of English Education), 2(4), 461. https://doi.org/10.22460/project.v2i4.p461-465

Tracey, D. H. (2016). Understanding the reading process: One path to strengthening classroom instruction. Education and Urban Society,49(9), 814831. https://doi.org/10.1177/0013124516659526

Giusto, M., \& Ehri, L. C. (2018). Effectiveness of a partial read-aloud test accommodation to assess reading comprehension in students with a reading disability. Journal of Learning Disabilities, 52(3), 259270. https://doi.org/10.1177/0022219418789377

Simos, P. G. (2020). Reading, reading acquisition, and reading disability (Dyslexia). Fifty Years of Magnetoencephalography, 265277. https://doi.org/10.1093/oso/9780190935689.003.0018 